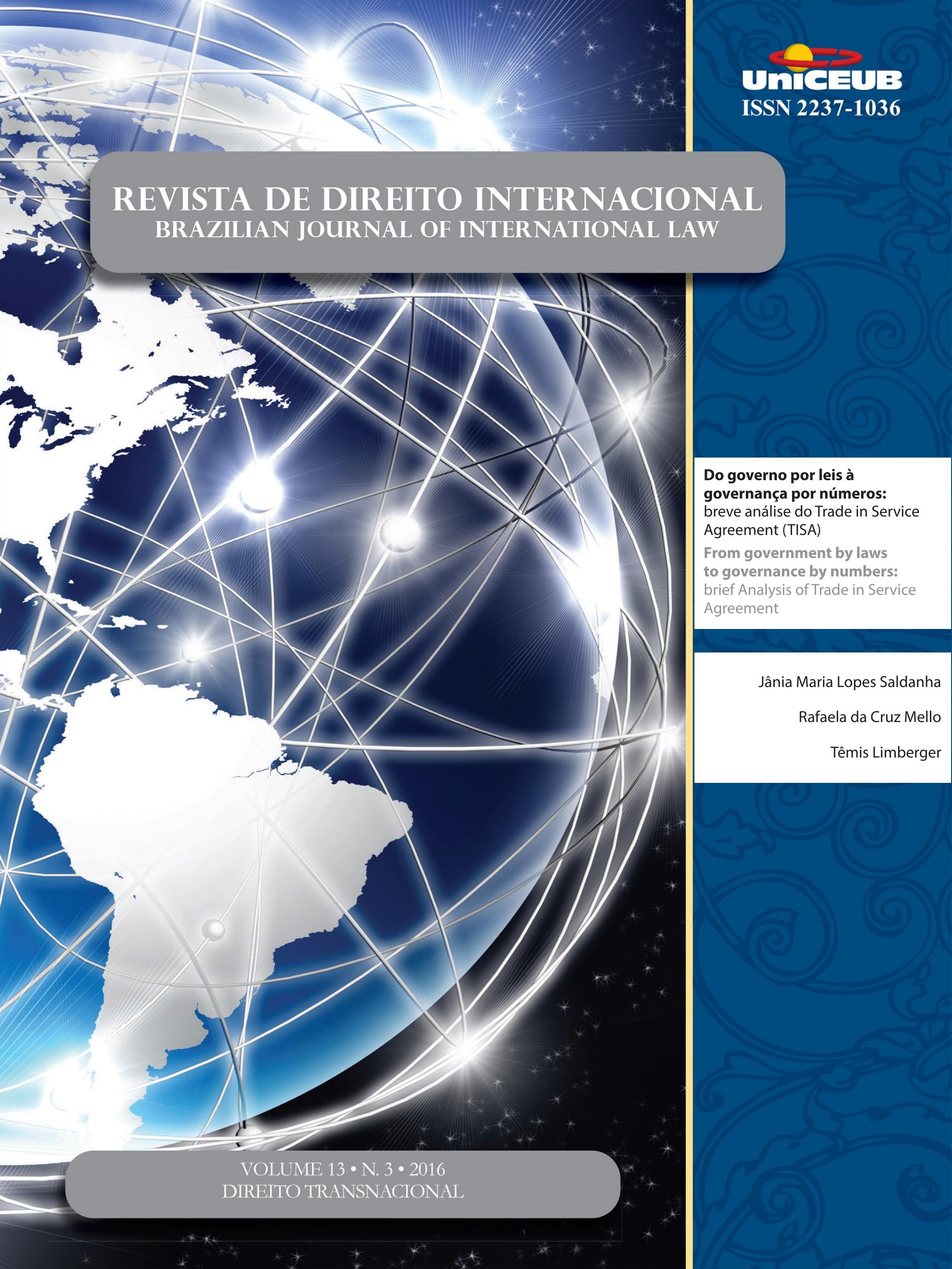


Crônicas da ATUALIdAde do direito internacional .................................................. 2

I. Dossiê Temático: Direito Transnacional .........................................................15

EDITORIAL: O Direito Transnacional - Circulação de normas e relações jurídicas transnacionais .......16 Priscila Pereira de Andrade

A emergênCia do direito transnacional ambiental .............................................18 Priscila Pereira de Andrade

Desafíos y RESPUESTAS TRANSNACIONALES FRENTE A LOS CRÍMENES AMBIENTALES ...............30 Rosmerlin Estupiñan-Silva

DiREITO TRANSNACIONAL E MUdANÇAS CLIMÁTICAS .50 Géraud de Lassus Saint-Geniès

Especies en movimiento: la Convención sobre el Comercio Internacional de Especies Amenazadas de Fauna y Flora Silvestres como espacio de “Encuentro” de discursos, ACTORES Y ESTRATEGIAS EN EL DERECHO AMBIENTAL TRASNACIONAL

María Valeria Berros e Dabel Leandro Franco

El carácter transnacional del Sistema comunitario de ECogestion « Eco-ManageMENT AND Audit SCHEME » (EMAS) DENTRo de LA UE y MÁs ALlÁ DE SUS Fronteras ......72 Adélie Pomade

O CONCEITO DE CONDUTA EMPRESARIAL RESPONSÁVEL À LUZ DOS ORDENAMENTOS JURÍDICOS BRASILEIRO, INTERNACIONAL E TRANSNACIONAL

Gabriel Webber Ziero

ARBITRAGEM NO DIREITO TRIBUTÁRIO INTERNACIONAL E NO DIREITO INTERNACIONAL DOS INVESTIMENTOS: UMA MANIFESTAÇÃO DO DIREITO TRANSNACIONAL

Vivian Daniele Rocha Gabriel 
O DIREITO TRIBUTÁRIO SOB UMA PERSPECTIVA TRANSNACIONAL

Franciele de Simas Estrela Borges

As Características do Direito Transnacional como Metodologia: Análise sob o enfoQue dos Aspectos Processuais da Arbitragem 126

Flávia Foz Mange

O DIREITO TRANSNACIONAL (“GLOBAL LAW") E A CRISE DE PARADIGMA DO ESTADO-CENTRISMO: É POSSÍVEL CONCEBER UMA ORDEM JURÍDICA TRANSNACIONAL? ...................................... 146

Luiza Nogueira Barbosa e Valesca Raizer Borges Moschen

TransPorte AÉREO E DIREITO TRANSNACIONAL: DA CONVERGÊNCIA À UNIFORMIDADE 160 Mickael R. Viglino

Outros Artigos. 175

O Fundo Monetário Internacional e a proteção dos direitos humanos: uma análise DO PROGRAMA DE CRESCIMENTO E REDUÇÃO DA POBREZA NO HAITI 177

Pablo Henrique Hubner de Lanna Costa e Carlos Alberto Simões de Tomaz

Um estranho no ninho? Padrões privados no Acordo de Barreiras Técnicas ao CoMÉRCIO DA OMC 192

Michelle Ratton Sanchez Badin e Marina Yoshimi Takitani

Os benefícios tributários do programa Inovar-Auto e os princípios da Nação Mais Favorecida e do Tratamento Nacional: uma análise dos argumentos dos Painéis atualmente em Curso contra o Brasil no Órgão de SoluÇão de Controvérsias da OMC . 211 Eric Moraes Castro e Silva

A ERA DA HUMANIDADE: REFLEXões PARA A HISTÓRIA DO DIREITO INTERNACIONAL 236 Henrique Weil Afonso

Precedentes vinculantes nos Estados Unidos da América e no direito brasileiro: Um ESTUDO COMPARADO 264

Patrícia Perrone Campos Mello 
IL DIRITTO AMBIENTALE SECONDO L'OTTICA DEL DIRITTO COSTITUZIONALE POSITIVO E LA RESPONSABILITÀ PER DANNI ALL'AMBIENTE NEL DIRITTO COMUNITARIO: LO STATO DELL'ARTE DEL DIRITTO AMBIENTALE COSTITUZIONALE E COMUNITARIO 287

Elcio Nacur Rezende

DA DESCONSIDERAÇÃo DA PERSONALIDADE JURÍDICA NAS RELAÇÕES CONSUMEIRISTAS BRASILEIRAS: ANÁLISE À LUZ DAS TEORIAS CLÁSSICAS

Daniel Amin Ferraz e Marcus Vinicius Silveira de Sá

ANALYSIS OF ADVANTAGES AND DISADVANTAGES OF FORUMS PRESCRIBED UNDER THE UNCLOS AND STATE PRACTICE: THE WAY AHEAD FOR INDIA ......................................................319

Vinai Kumar Singh

Do governo POR LEIS À governanÇA POR NúMERos: breve anÁlise do Trade in SERVICE AgreEMENT (TISA) ...............................................................................338 Jânia Maria Lopes Saldanha, Rafaela da Cruz Mello e Têmis Limberger

As DIRETIVAS EUROPEIAS COMO NORMA REGULADORA DO DIREITO ADMINISTRATIVO GLOBAL ..356 Alice Rocha da Silva e Ruth Maria Pereira dos Santos

O desenVolvimento da POlítica AGRícola COMUM dA UNião EUROPEIA 375 Tatiana de A. F. R. Cardoso Squeff

A imunidade de Jurisdição das organizaÇões internacionais FaCE AO Direito de aCESSO À JUSTIÇA 391

Fernanda Araújo Kallás e Caetano

O DIREITO INTERNACIONAL ENTRE O DEVER ÉTICO E A AÇÃo POLÍ́TICA: OS FUNDAMENTOS DE UM DEVER DE COOPERAÇÃO INTERNACIONAL NA FILOSOFIA POLÍTICA DE IMMANUEL KANT .405 Ademar Junior Pozzatti

EXTENSÃo E FRAGMENTAÇÃo NO CONTEXTO DA JURISDIÇÃO PENAL INTERNACIONAL .423 Marcus Vinícius Xavier de Oliveira

A DEFINiÇÃo JURÍdiCA DA "COMUNIDADE" .444 Nitish Monebhurrun, Michelle Lucas Cardoso Balbino, Fernanda Castelo Branco Araujo, Othon Pantoja, Míara Bogo Bruno e Cândida Dettenborn Nóbrega 
Comparative Study on Chinese Local Legislation of Science and Technology ProGRESS

LI Xiaoming e LI Yihan

O CONTROLE PENAL DO TRÁFICO DE PESSOAS: CONSTRUÇÃO JURÍDICA, INTERAÇÕES ORGANIZACIONAIS E COOPERAÇÃO INTERNACIONAL

Bruno Amaral Machado e Priscilla Brito Silva Vieira

Desativismo judicial: a extradição Battisti no Supremo Tribunal Federal .505 Francisco Rezek e Israel Paulino

A decisão norte-americana do Caso Myriad: novos paradigmas para a Proteção patenTÁRIA DO CÓDIGO GENÉTICO HUMANO E BIOTECNOLOGIA 514 José Carlos Vaz e Dias e Clarisse De La Cerda 


\section{Do governo por leis à governança por números: breve análise do Trade in Service Agreement (TISA)*}

\author{
From government by laws to governance \\ by numbers: brief Analysis of Trade in Service \\ Agreement
}

\author{
Jânia Maria Lopes Saldanha** \\ Rafaela da Cruz Mello*** \\ Têmis Limberger****
}

* Recebido em 15/07/2016

Aprovado em 24/11/2016

** Pós-Doutora em Direito pelo IHEJ - Institut des Hautes Études sur la Justice, Paris. Doutora em Direito Público. Professora Associada do Programa de Pós-Graduação em Direito e do Departamento de Direito da UFSM. Advogada. E-mail: janiasaldanha@gmail.com

*** Advogada. Mestranda em Direito pela Universidade Federal de Santa Maria vinculada a linha de pesquisa em Direitos da Sociedade em Rede. Participante do CCULTIS (Centro de Cultura Jurídicas Comparadas, Internacionalização do Direito e Sistemas de Justiça). E-mail: rafaelacruzmello@gmail.com

\section{Resumo}

O artigo propõe-se a analisar, em um contexto de globalização, o fenômeno de ressignificação de estruturas delineadas na modernidade, como é o caso do Estado, do direito e do governo. Partindo-se da noção de que as relações transnacionais que permeiam a paisagem político-jurídica atual são incapazes de ser compreendidas somente com conceitos advindos da modernidade, examina-se a estética do caos jurídico, da formação de um direito transnacional e das tentativas de superação de um governo por leis por uma governança por números. Essa tentativa é demonstrada pela substituição do sonho moderno da harmonia jurídica pelo cálculo matemático pelo atual ideal de harmonia pela estatística. As regras clássicas de direito passam a conviver com o crescimento de normas programáticas que estimulam o poder das empresas transnacionais e os valores de mercado ao fomentarem a processos de desregulamentação e de concorrência entre os sistemas jurídicos a fim de atender aos interesses econômicos. Utilizando-se o método de abordagem dialético para opor a incompletude das ideias diante da força da realidade, a análise desse cenário será feita a partir de revisão bibliográfica e da observação do Acordo sobre Comércio de Serviços (TIS A), acordo entre diversos países que tem como objetivo velado a privatização de serviços públicos e a desregulamentação para favorecer grandes empresas. Conclui-se que o TIS $A$ serve para corroborar a afirmação de que a globalização fomenta a passagem de um governo por leis para uma governança por números, a qual gera mudanças tanto na sociedade internacional como nos sistemas jurídicos internos dos Estados.

Palavras-chave: Governo por leis; Governança por números; Direito transnacional.
**** Doutora em direito público pela Universidade Pompeu Fabra (Barcelona/Espanha), com estudos pós-doutorais pela Universidade de Sevilha (Espanha), mestrado e graduação em direito pela UFRGS. Professora junto ao PPG em Direito da Unisinos e Procuradora de Justiça (MP/RS). E-mail: temis@via-rs.net 


\section{Abstract}

The article proposes to examine, in a context of globalization and globalization of international actors, the reframing phenomenon outlined structures in modernity, as is the case of the state, law and government. Starting from the notion that transnational relations that permeate the current political and legal landscape are unable to be understood only with concepts arising from modernity, examines the aesthetics of legal chaos, the formation of a transnational law and overcoming attempts a government by laws by governance by numbers. This attempt is demonstrated by the substitution of the modern dream of legal harmony by mathematical calculation by the current ideal of harmony by statistician. The classic rules of law go to live with the growth of program standards that stimulate the power of transnational companies and the market values to encourage competition between legal systems and deregulation in order to meet the economic interests. Using the dialectical method to oppose the incompleteness of ideas on the nature of things, the analysis of this scenario will be made from literature review and observation of the Trade in Service Agreement (TIS A), agreement between several countries which aims veiled privatization of public services and deregulation to favor large companies. We conclude that the TIS $A$ serves to corroborate the claim that globalization promotes the passage of a government by laws for governance by numbers, which generates changes in both the international community and the domestic legal systems of States.

Keywords: Government by law; Governance by numbers; Transnational law.

\section{INTRODUÇÃO}

Em junho de 2016, por meio de uma decisão política do governo provisório de Michel Temer, na Confederação Nacional da Indústria (CNI), houve o anúncio da pretensão brasileira de integrar o grupo de países que estão participando das negociações do Acordo Internacional de Comércio de Serviços (Trade in Service Agreement - TIS A). As tratativas de tal acordo vem, desde 2012, sendo realizadas a portas fechadas ${ }^{1}$ entre diversos

1 De grande relevância, a colocação de que o acordo vem sendo realizado a portas fechadas entre os países participantes. Isso porque países, dentre eles Estados Unidos, Canadá, México e alguns países da União Europeia, configurando verdadeira espinha dorsal nos campos jurídico, político e econômico de novas configurações do mercado mundial.

A grande polêmica em torno desse novo acordo que dispõe sobre comércio de serviços é que ele vem sendo negociado a portas fechadas por governos, sob a influência de grupos de empresas transnacionais, constituindo-se como verdadeiro risco às leis e regramentos feitos de modo democrático no âmbito dos Estados. O TIS $A$ surge em um contexto de alarmante crescimento e preponderância das questões de mercado sobre os valores de interesse geral das sociedades democráticas. Isso porque se configura como um tratado de livre comércio fundado no poder de empresas transnacionais cuja preocupação é de que as tentativas de institucionalização e juridicização a favor dos interesses comerciais passem a inviabilizar ações governamentais em áreas que desfavoreçam os interesses econômicos de transnacionais e conglomerados empresariais.

No contexto da globalização econômica e de multiplicação de atores internacionais e sujeitos de direito internacional, a vida pública passa a ser, fortemente, afetada por interesses privados e a arquitetura social atual gera porosidades e fragmentações dentro dos Estados e fora deles, assim como opera modificações significantes nos campos jurídicos internos e internacionais. $\mathrm{O}$ direito torna-se transnacional, contendo elementos hiper e antimodernos, com a exacerbação e radicalização de algumas características vindas da racionalidade moderna e a ruptura estrutural com outros elementos.

A generalidade e a pretensão de certeza do direito moderno, bem como a manifestação deste por meio de um governo por leis passa a conviver com a estrutura globalizada de uma governança por números que serve aos interesses particulares de grupos e conglomerados econômicos. Nesse cenário, o problema de pesquisa que norteia o presente trabalho é o que segue: na estética do caos oriunda da globalização econômica, de que maneira acordos de livre comércio como o TIS $A$ corroboram

o caráter de sigilosidade impede o amplo acesso a fontes primárias em relação ao acordo. Diante de tal fato, metodologicamente, optou-se pelo termo observações em vez de análise em relação ao TIS $A$, uma vez que o acesso a fontes primárias foi limitado diante da praticamente ausência de disponibilidade da integralidade do texto do tratado, tendo-se optado pela ampliação, no presente trabalho, do uso de fontes secundárias, tais quais relatórios e textos científicos que abordam o TIS $A$. 
a desordenada e perigosa governança por números?

Utilizando-se do método dialético de abordagem e da percepção de tal método de que o mundo é composto por processos complexos e inacabados e não por estruturas fixas, o principal objetivo será o de apresentar um estado da arte da atual convivência recíproca na ordem transnacional de um governo por leis, enquanto herança da modernidade e uma governança por números, com o constante crescimento da segunda situação em detrimento da primeira. O caso TIS $A$ será exposto a fim de exemplificar essa situação.

Para tanto, o artigo divide-se em duas grandes partes, na oposição entre incompletude das ideias diante da força da realidade. A primeira delas apresenta a incompletude das ideias demonstradas hoje pela estética do caos na paisagem jurídica e pela fragilização do moderno governo por leis. Na segunda parte, a fim de demonstrar que o que revela ainda mais a incompletude das ideias é a força das coisas e da realidade, serão abordados os efeitos globais da governança por números, com a exposição do TIS A como exemplificação do crescimento de estruturas que corroboram a existência de uma governança por números que atende aos ideais de mercado e de naturalização de um direito econômico no fragmentário cenário transnacional.

\section{DA INCOMPLETUDE DAS IDEIAS: ESTÉTICA DO CAOS E A FRAGILIZAÇÃO DO GOVERNO POR LEIS}

A contrariedade entre a incompletude das ideias e a força das coisas é uma das premissas que guia o trabalho de Mireille Delmas-Marty no primeiro livro da coleção "As forças imaginantes do direito". Nessa relação, ela analisa as vicissitudes da mundialização ${ }^{3}$ e as

2 DELMAS-MARTY, Mireille. Les forces imaginantes du droit: Le relatif et l'universel. Paris. Seuil. 2004.

3 Na obra "Três Desafios para um Direito Mundial", Mirelle Delmas-Marty observa as particularidades dos termos globalização, mundialização e universalidade, quais sejam: "A mundialização remete à difusão espacial de um produto, de uma técnica ou de uma ideia. A universalidade implica um compartilhar de sentidos". Em outra passagem, disserta: "Difusão espacial de um lado, compartilhar os sentidos de outra, estas duas fórmulas descrevem muito bem a diferença que separam os dois fenômenos que eu denominarei globalização para a economia e universalização para os direitos do homem, guardando assim o termo mundialização uma neutralidade que ele jamais perderá, caso não se resigne rapidamente ao primado da economia consequências desta para a seara jurídica por meio da oposição entre as falhas de um universalismo jurídico, visto no patamar de incompletude das ideias e os limites do relativismo jurídico, compreendido enquanto força das coisas.

Embora não abordando questões do universalismo e do relativismo, este trabalho fará uso dessa ótica dicotômica de Delmas-Marty para compreender o fenômeno da ordem jurídica na mundialização e a convivência entre governo por leis e governança por números, com o crescimento dessa última em detrimento do primeiro. Dessa forma, o que se demonstrará neste artigo, nesse primeiro momento, é que o direito e o Estado são estruturas que, a partir da modernidade, imbricam-se de modo muito forte. O racionalismo moderno faz com que a estrutura de um governo por leis seja o modelo ideal tanto em âmbito interno quanto para a sociedade internacional.

Os ideais de segurança da modernidade dão lugar na mundialização a uma estrutura anárquica e de caos jurídico multinível. As relações entre direito internacional e direito interno no cenário contemporâneo, por exemplo, ultrapassam as clássicas teorias do monismo e do dualismo cedendo espaço a uma dimensão transnormativa de comunicação entre as diferentes ordens jurídicas. Nesse contexto, somado à multiplicidade de atores internacionais, delineia-se o, ainda, incipiente e confuso direito transnacional, que é palco para o desenvolvimento de traços de uma governança por números.

\subsection{O reino da lei na tradição moderna ocidental e o sonho da harmonia pelo cálculo}

Insta, primeiramente, salientar o local sobre o qual se fala nessa exposição. Seria ingênuo compreender o mundo como uma unidade homogênea, mesmo pensando desde os primórdios da história. Assim, culturas distintas, religiões diferentes e compreensões sobre o mundo e o universo que destoam entre si, sempre, estiveram e, sempre, estarão presentes no planeta. Segundo Alain Supiot ${ }^{4}$, mesmo a mundialização, com suas carac-

sobre os Direitos do Homem". (DELMAS-MARTY, Mireille. Três desafios para um Direito Mundial. Tradução Fauzi Hassan Choukr. Rio de Janeiro: Lúmen Júris, 2003, p. 08-09).

4 SUPIOT, Alain. État social et mondialisation: analyse juridique des solidarités. In: Cours "De la gouvernement par le lois à la gouvernance par les nombres. Collége de France, 2013. Disponível em: https://www.college-de-france.fr/media/alain-supiot/ 
terísticas híbridas e instáveis, não possui a pretensão de globalizar um pensamento como único, mas de fazer dialogar as diferentes formas de pensamento a partir de um jogo recíproco de influências.

Isso é dito com a finalidade de afirmar que, neste trabalho, teorias serão trazidas com base em determinados elementos e determinadas bases. No caso, ao trabalharmos as questões de Estado, governo e direito (principalmente a estrutura de civil law), trabalhamos com as estruturas de um pensamento ocidental que, em grande medida, são resultados de criações e modificações da (e na) modernidade e que, em dias atuais, configuram-se como categorias que devem ser, constantemente, revistas e (re)indagadas.

Ao fim do século XX e início do século XXI, o contexto de mundialização potencializou o surgimento de figuras híbridas nos planos internacional, regional, nacional e local. Entretanto, a despeito das mudanças advindas da proliferação dos híbridos, é inegável que, ainda hoje, um dos principais atores (e sujeito de direitos) da sociedade internacional ainda são os Estados.

Como bem destaca Jacques Chevallier ${ }^{5}$, o Estado não poderia ser considerado como uma forma de organização política ultrapassada, pois, mesmo confrontado com diferentes figuras trazidas no seio da mundialização, ele, ainda, persiste tanto como princípio fundamental de integração social e formação de identidades em âmbito interno quanto como elemento essencial de organização da vida internacional. O desenhar do Estado na modernidade desenvolveu-se de modo que o direito se tornasse uma realidade intrinsecamente ligada a ele, como forma de organização política cuja institucionalização passa pelo campo jurídico.

Compreender a realidade híbrida e transnacional da sociedade internacional atual passa pela necessidade de compreensão das relações históricas entre Estado e direito da modernidade até os dias atuais. Se um dos grandes motores da Revolução Francesa do século XVIII foi a necessidade burguesa de possuir poder político para além do poder econômico, um de seus maiores reflexos foi a passagem do Estado moderno de sua versão absolutista, com os poderes concentrados nas mãos da figura de um soberano, para sua versão liberal, em que o poder político, conquistado pela classe econômica emergente

UPL2335835739398687161_supiot.pdf. Acesso em 15 jun 2016. 5 CHEVAlLIER, Jacques. O Estado Pós-Moderno. Tradução de Marçal Justen Filho. Belo Horizonte: Fórum, 2009, p. 23. passou a ser legitimado por um acordo político-jurídico denominado Constituição.

Os anseios burgueses de segurança passaram no modelo de Estado liberal a serem baluartes para a construção jurídica estatal. Se, no âmbito interno, encontra-se a figura de uma organização política dividida de modo rigoroso entre as funções legislativa, executiva e judiciária e permeado de valores como liberdade e propriedade privada, no âmbito externo, vislumbra-se uma sociedade internacional de Estados livres, soberanos e com prerrogativas de igualdade entre si.

Com maior expressividade dentro dos Estados, o direito, na modernidade ocidental, se estrutura sob a forma de leis abstratas e universais, sistematizadas em códigos. A razão enquanto principal característica moderna dota de universalidade o direito, pois, como assevera Benôit Frydman', a ótica individual de que a natureza é a mesma para todos os seres que sejam dotados de razão faz emergir a ideia de um direito universal com regras gerais e abstratas.

Soma-se a isso o fato de que a ideia de um direito puramente racional se funda em um projeto científico considerado revolucionário: edificar o direito de modo igual ou semelhante à matemática. Assim, o sonho da harmonia pelo cálculo ${ }^{7}$ enquanto característica moderna, se revela pelo fato de que, diferentemente do método dos Antigos, que se fundava sob a premissa de que o direito era dado a partir de um caso real ou ficcional, considerando as particularidades de cada situação, os modernos acreditavam que a solução de um caso se encontrava na aplicação de uma fórmula, de uma lei geral e abstrata.

Segundo Benôit Frydman ${ }^{8}$ a racionalização moderna do direito o submete ao denominado Tratado de Geometria: parte-se de um pequeno número de proposições simples e evidentes (axiomas) lhes combinando nas demonstrações formais a fim de deduzir progressivamente as regras. O conjunto encontrado formará um sistema unívoco, coerente e completo à imagem de um sistema lógico. Esse modelo explica o reinado da lei e do legislador na tradição jurídica moderna ocidental.

6 FRYDMAN, Benôit. Citoyen, Droit \& Societé: Les transformations du droit moderne. Bruxelas: Fundación Roi Baudouin, 1998, p. 17. 7 SUPIOT, Alain. La Gouvernance par les nombres. Nantes: Fayard: Poids et mesures du monde, 2015.

8 FRYDMAN, Benôit. Citoyen, Droit \& Societé: Les transformations du droit moderne. Bruxelas: Fundación Roi Baudouin, 1998, p. 18. 
Isso porque o silogismo predomina na lógica jurídica, de modo que a premissa maior é a lei na sua forma geral e abstrata, produzida pelo legislador; a premissa menor é a situação fática apresentada e a conclusão é a decisão dada pelo magistrado. A modernidade, de modo antagônico ao medievo, colocou o homem como centro do universo e a razão como meio de revelar verdades absolutas, trazendo para o direito a prática do dedutivismo lógico-subsuntivo: como uma equação matemática, admite-se, apenas, uma resposta correta e a busca desta - que estaria nas hipóteses aventadas pela legislação leva à ausência de comprometimento com a realidade e com o caso concreto.

O reinado da lei é sustentado, portanto, no sonho da harmonia pelo cálculo, pela aproximação do direito às ciências exatas e à lógica matemática, com o Estado sendo a única fonte produtora do direito, que é produzido verticalmente. Desse modo, ressalta Jacques Chevallier ${ }^{9}$ que o direito é expressão e vetor da modernidade, possuindo sob a égide desta as características de encarnação da razão, subjetivação do indivíduo e fetichismo da regra.

Todavia esse paradigma racional de harmonia pelo cálculo que sustenta a ideia de um governo por leis acaba sendo questionado e as pressões sociais em busca de prestações estatais positivas, bem como a preocupação com direitos sociais faz com que, a partir de meados do século XIX, os rumos do Estado se modifiquem de modo que o Estado liberal, por meio de suas novas atribuições passe a ser Estado social ou Estado-providência.

Nesse modelo, o governo por leis, bem como o reinado dos legisladores acaba tendo que conviver com um poder executivo que, por meio de políticas públicas busca a efetivação de direitos sociais, econômicos e culturais para além dos direitos civis e políticos e com um poder judiciário mais ativista. Assim, o projeto liberal moderno teve consequências como o progresso econômico, a valorização do indivíduo em perspectiva subjetiva e o poder legal sendo baseado no direito estatal, o qual possuía a estrutura de uma pirâmide, com a norma fundamental no topo.

Nesse panorama há a formação de uma concepção individualista e formal da liberdade e isso somado a fa-

9 CHEVAlLIER, Jacques. O Estado Pós-Moderno. Tradução de Marçal Justen Filho. Belo Horizonte: Fórum, 2009, p. 117. tores como a Revolução Industrial, com a formação de uma classe operária, a crise de 1929 e as duas grandes guerras mundiais fizeram com que o Estado deixasse de lado sua postura absenteísta moderna, passasse a intervir na economia e agir mais ativamente na sociedade, tendo a justiça social como princípio basilar.

Nessa configuração de Estado, segundo Cristiano Becker Isaia ${ }^{10}$, a lei funcionaria mais como meio de acesso à ação concreta estatal e menos como ordem geral e abstrata. Consoante fora referido, o reinado da lei e a concentração de poderes na figura do legislador acabam cedendo espaço a um poder judiciário mais ativo em âmbito interno. Os juízes passam a atuar de modo ativista, rompendo com o distanciamento da sociedade propiciado pelo dedutivismo lógico-subsuntivo e deixando de serem meros espectadores para se tornarem sujeitos ativos do processo.

Como ponto em comum desses dois modelos de Estado, está o risco, enquanto princípio da sociedade moderna. François Ost ${ }^{11}$ explica essa afirmação asseverando que é como Estado protetor que o Estado moderno se identifica. Desse modo, o Estado liberal, no século XIX, apresenta a proteção de forma minimalista da garantia generalizada da sobrevivência e o Estado Social, no século XX, assume, para além da sobrevivência, a garantia de certa qualidade de vida aos cidadãos, na tentativa de dominar os riscos sociais e garantir segurança.

Esse último modelo, na década de 1970, começa a apresentar sinais de crise, que, para além do campo econômico, se traduz em crises de eficácia, de legitimidade, racionalidade e identidade ${ }^{12}$. Como bem refere Ost ${ }^{13}$, a sociedade assistencial desagrega-se juntamente à noção de justiça social e sociedade voluntarista, o mercado e a privatização triunfam e a noção de um governo por leis é abalada pelo ideal crescente de uma governança por números, com índices, rankings e indicadores oriundos de entidades privadas que se inserem em estruturas públicas.

10 ISAIA, Cristiano Becker. Processo civil e hermenêutica: crise do procedimento ordinário e o redesenhar da jurisdição processual civil pela sentença (democrática) liminar de mérito. Curitiba: Juruá, 2012, p. 140.

11 OST, François. O tempo do direito. Tradução de Maria Fernanda Oliveira. Lisboa: Instituto Piaget, 1999, p. 336.

12 FRYDMAN, Benôit. Citoyen, Droit \& Societé: Les transformations du droit moderne. Bruxelas: Fundación Roi Baudouin, 1998, p.46.

13 OST, François. O tempo do direito. Tradução de Maria Fernanda Oliveira. Lisboa: Instituto Piaget, 1999, p. 337. 
O direito, portanto, é atingido. Fortemente. por essa mudança de paradigma. Como afirma Benôit Frydman ${ }^{14}$, as regras de direito passam a ser percebidas como complexas, incompreensíveis, efêmeras e, sobretudo, ineficazes ou absurdas na medida em que elas não atendem mais aos objetivos declarados pelos poderes públicos. As estruturas jurídicas, tanto em âmbito interno quanto na sociedade internacional inserem-se em um contexto complexo de caos, de movimentos de sístole e diástole, de aproximação com elementos modernos na forma de estruturas hipermodernas e de rompimento com a modernidade (antimoderno).

A estrutura piramidal cede espaço às redes, aos anéis normativos que se intercruzam e se interpenetram formando uma verdadeira estrutura transnacional. Sobretudo no campo de comunicação entre direito interno e direito internacional, as teorias clássicas do monismo e do dualismo fragmentam-se no sentido de ceder espaço a uma dialética constante, à concorrência internormativa e à deslocalização da produção de normas jurídicas ${ }^{15}$. É nessa estética do caos e no panorama da incompletude das ideias que começa a se delinear uma dimensão transnormativa e transnacional, na qual o direito e as relações jurídicas multiníveis são, enormemente, afetadas.

\subsection{A estética do caos e o panorama transnacional no direito.}

As fronteiras físicas e simbólicas que delimitavam a esfera de influência dos Estados tornaram-se porosas na segunda metade do século XX. A transnacionalidade é a marca da sociedade após a Segunda Guerra Mundial, de modo que, conforme assevera Jacques Chevallier ${ }^{16}$, os Estados passaram a ser atravessados por fluxos das mais diversas ordens, que não são capazes de se controlar, canalizar ou conter.

O direito, conforme se falou anteriormente, não fica alheio a essas mudanças. A crise da modernidade jurídica leva à substituição da figura piramidal de direito com a unicidade do Estado enquanto produtor de regras ju-

14 FRYDMAN, Benôit. Citoyen, Droit \& Societé: Les transformations du droit moderne. Bruxelas: Fundación Roi Baudouin, 1998.

15 MENEZES, Wagner. O direito internacional contemporâneo e a teoria da transnormatividade. In: PENSAR: Revista de Ciências Jurídicas. Vol. 12, no 1, 2007. Disponível em: http://ojs.unifor.br/ index.php/rpen/article/view/1084. Acesso em 18 jun 2016.

16 CHEVALLIER, Jacques. O Estado Pós-Moderno. Tradução de Marçal Justen Filho. Belo Horizonte: Fórum, 2009, p. 32. rídicas gerais em um sistema estável por uma estrutura anárquica, com proliferação excessiva de regras específicas produzidas pelos mais diversos atores da sociedade internacional, hierarquias entrelaçadas e competências concorrentes comuns ${ }^{17}$.

A paisagem jurídica hoje, ao contrário do que foi legado - ou instigado - pelos primeiros modernos é imprecisa, incerta e instável, ou, como afirmam os franceses: flou (impreciso), doux (doce) e o mou (suave) ${ }^{18}$. Segundo Wagner Menezes ${ }^{19}$, as interações normativas dinâmicas que ocorrem no seio da sociedade internacional, em tempos de mundialização, propiciam o estabelecimento de um sistema de comunicação jurídica multinível, gerando relações transnormativas entre direito internacional e direito interno.

Wagner Menezes ${ }^{20}$, nesse sentido menciona que a conjunção de relações jurídicas, para além das fronteiras nacionais em consonância com interações normativas dinâmicas, levam a essa transnormatividade. Assim, o direito transnacional, na forma descrita por Philip Jessup $^{21}$ configura-se como o conjunto de normas e regras capazes de regular atos ou fatos que transcendem fronteiras nacionais, tanto na esfera de um direito público quanto na esfera de um direito privado, bem como em relação a outras regras que não se enquadram nas categorias jurídicas clássicas.

Philip Jessup cunha, em relação ao direito no pós $2^{\circ}$ Guerra Mundial, observa que o século XX caminhou no sentido de romper com alguns dos pilares políticos e jurídicos traçados pela modernidade. Se, no século XIX, a sociedade internacional possuía suas bases sobre o princípio da soberania estatal, o século XX e, princi-

17 VARELLA, Marcelo. Internacionalização do Direito: superação do paradigma estatal e a insuficiência das estruturas de diálogos. In: Revista de Direito Internacional - Brazilian Journal of International Law. Vol. 9, nº4, 2012. Disponível em: http://www.publicacoesacademicas.uniceub.br/index.php/rdi/article/view/2203/pdf. Acesso em 14 jul 2016.

18 CHEVALLIER, Jacques. O Estado Pós-Moderno. Tradução de Marçal Justen Filho. Belo Horizonte: Fórum, 2009, p. 116.

19 MENEZES, Wagner. O direito internacional contemporâneo e a teoria da transnormatividade. In: PENSAR: Revista de Ciências Jurídicas. Vol. 12, no 1, 2007. Disponível em: http://ojs.unifor.br/ index.php/rpen/article/view/1084. Acesso em 18 jun 2016.

20 MENEZES, Wagner. O direito internacional contemporâneo e a teoria da transnormatividade. In: PENSAR: Revista de Ciências Jurídicas. Vol. 12, no 1, 2007. Disponível em: http://ojs.unifor.br/ index.php/rpen/article/view/1084. Acesso em 18 jun 2016.

21 JESSUP, Philip C. Direito Transnacional. Tradução Carlos Ramires Pinheiro da Silva. Rio de Janeiro: Fundo de Cultura, 1965. 
palmente, o incipiente século XXI radicaliza com alguns elementos da modernidade e rompe, abruptamente, com outros.

No domínio jurídico, observam-se, nitidamente, essas mudanças. A crise da racionalidade jurídica que afeta o direito tanto internamente quanto no seio da sociedade internacional leva ao abalo dos atributos da generalidade, estabilidade e sistematicidade. Nesse sentido, o sonho da harmonia pelo cálculo e pela elaboração de teoremas matemáticos passa a ser substituída pelo sonho da harmonia pela estatística com a proliferação de normas oriundas de entes privados como indicadores, rankings e standards.

Segundo Benôit Frydman ${ }^{22}$, o panorama do século XXI de liberalização e desenvolvimento de relações e de trocas entre os diferentes atores internacionais reflete-se em três setores de observação, os quais interferem, diretamente, um nos outros: o primeiro deles é o setor da economia, com o desenvolvimento de um novo modelo macroeconômico caracterizado pela ampliação das empresas transnacionais e pela deslocalização da produção industrial, com novos canais globais de troca de mercadorias e escoamento de produtos.

O segundo setor observado é o da revolução tecnológica, com a reconceituação de termos como tempo e espaço a partir da extinção das distâncias físicas entre os homens e de fronteiras para a circulação de bens e capitais. A soma desses dois campos de observação, sendo o primeiro, nas palavras de Alain Supiot ${ }^{23}$, um fenômeno conjuntural e o segundo. um fenômeno estrutural, formam a utopia de um Mercado Total, situação que afeta, diretamente, a observação do terceiro domínio que é o político-jurídico.

Neste vislumbra-se o aumento da quantidade de atores internacionais com hierarquias entrelaçadas nos mais diversos níveis (local, nacional, regional, supranacional e internacional), além de objetos jurídicos fugindo dos padrões legislativos clássicos, de competências concorrentes e de tecnicidade específica das leis. O direito moderno em sua estrutura piramidal e com a primazia de um governo por leis é substituído por um

22 FRYDMAN, Benôit. La concurrence normative européenne et globale. Bruxelas: Centre Perelman de Philosophie du droit, 2016. Disponível em: http:/ / www.philodroit.be/La-concurrence-normative-europeenne-et-globale?lang=fr. Acesso 30 jun 2016.

23 SUPIOT, Alain. O Espírito de Filadélfia. A justiça social diante do mercado total. Tradução de Tânia do Valle Tschiedel. Porto Alegre: Sulina, 2014, p. 54. direito contemporâneo no formato de redes ou, como refere Delmas-Marty ${ }^{24}$, de estruturas anárquicas, anéis em formatos de guirlanda proporcionando um cenário de verdadeiro caos jurídico em razão de um pluralismo desordenado e com primazia de uma governança por números, em que indicadores e standards adquirem uma enorme importância no sentido de produção normativa e avaliação dos sistemas jurídicos.

Assim, como bem refere Benôit Frydman ${ }^{25}$, ao observar a situação como um imenso tabuleiro de xadrez, embora os princípios modernos que codificam o direito internacional público e o direito internacional privado permaneçam os mesmos, as modalidades jurídicas se modificam pela multiplicação de atores e pela fluidez da movimentação das "peças" de uma "casa" até outra, de modo que o curso do jogo é alterado, bem como as relações de poder entre os próprios jogadores. Assim, a virada global do século XX coloca em xeque o nacionalismo metodológico ou a mirada nacional, nas palavras de Ulrich Beck ${ }^{26}$, uma vez que as relações transnacionais e suas implicações nas esferas jurídicas internacional e propriamente estatais não podem mais sem percebidas sob a perspectiva somente do Estado em sua concepção moderna.

Nesse sentido, Jânia Saldanha ${ }^{27}$ corrobora a postura de Ulrich Beck ao afirmar que as concepções clássicas do direito são débeis e incapazes de explicar a transição dos aparelhos institucionais para fazer a mediação entre o que é produzido pela "expertise" dos laboratórios, pelas reuniões de especialistas e por Parlamentos nacionais ou não. É necessário ultrapassar a visão nacional para compreender o hibridismo ${ }^{28}$ presente na paisagem jurí-

24 DELMAS-MARTY, Mireille. Les forces imaginantes du droit (II): Le pluralism ordonné. Paris. Seuil. 2006.

25 FRYDMAN, Benôit. La concurrence normative européenne et globale. Bruxelas: Centre Perelman de Philosophie du droit, 2016. Disponível em: http:/ /www.philodroit.be/La-concurrence-normative-europeenne-et-globale?lang=fr. Acesso 30 jun 2016.

26 BECK, Ulrich. La mirada cosmopolita o guerra es la pa₹. Traduccion de Bernardo Moreno Carillo. Barcelona: Paidós, 2005.

27 SALDANHA, Jânia. Cosmopolis. Edizioni Classi. Firenzi, Parigi, Porto Alegre, 2016, p. 276.

28 Sobre hibridismo veja-se: LATOUR, Bruno. Nous n'avons jamais été modernes. Essai d'anthropologie symétrique. Paris: La Découverte/ Poche, 2013. Sobre o hibridismo normativo no constitucionalismo latino-americano leia-se: SANTOS, Boaventura de Sousa. Refundación del Estado em la América Latina. Perspectivas desde uma epistemologia del sur. Instituto Internacional Derecho y Sociedad. Programa democracia y transformación global. Lima, 2010. Disponível em: http:// www.boaventuradesousasantos.pt/media/Refundacion $\% 20 \mathrm{del} \% 20$ Estado_Lima2010.pdf. Acesso em 10 jun 2016. 
dica atual, com a mistura de regras jurídicas produzidas de modo clássico com as incipientes normas técnicas e de gestão, resultados da lógica performática e de eficiência total do mercado.

O crescimento exponencial do poder das empresas transnacionais e conglomerados econômicos somado à expansão de ideias ultraliberais ${ }^{29}$ - neoliberalismo no campo econômico e neoconservadorismo no campo político e social - fazem como que essas empresas tornem-se principais operadoras no comércio mundial, a ponto de suplantar em alguns pontos o poder dos Estados. Prova disso é o fenômeno de concorrência normativa, capaz de gerar não só especulações no mercado financeiro como também fomentar figuras jurídicas, como é o caso do Law Shopping e do Fórum Shopping, ou seja, as empresas avaliam os sistemas jurídicos estatais a fim de perceber qual deles possui regras fiscais, ambientais, trabalhistas e empresariais mais favoráveis para seu estabelecimento.

Segundo Benôit Frydman ${ }^{30}$, essa é a base da chamada concorrência normativa ou internormatividade. Embora a concorrência seja um fenômeno, historicamente muito antigo, sua abordagem pelo direito é tardia (data de meados do século XX e intensifica-se no século XXI) sendo fruto de percepções jurídicas sob vieses econômicos e sociológicos. Assim, propagando-se a falsa ideia de um direito natural econômico, os direitos positivos nacionais são avaliados de acordo com um padrão de princípios que representam regras ditas fundamentais de naturalização do funcionamento de mercado.

A partir dessa premissa, organizações internacionais econômicas e financeiras como Banco Mundial, Fundo Monetário Internacional (FMI) e Organização Mundial do Comércio (OMC), em nome dos mecanismos de mercado e das liberdades de troca, supervisionam os sistemas jurídicos e as medidas normativas estatais que de algum modo possam interferir no domínio econômico e no interesse de multinacionais. Sob essa ótica, os Estados são compelidos a rever sua legislação interna a fim de que não contrarie os imperativos do comércio internacional.

29 SUPIOT, Alain. O Espírito de Filadélfia. A justiça social diante do mercado total. Tradução de Tânia do Valle Tschiedel. Porto Alegre: Sulina, 2014

30 FRYDMAN, Benôit. La concurrence normative européenne et globale. Bruxelas: Centre Perelman de Philosophie du droit, 2016. Disponível em: http://www.philodroit.be/La-concurrence-normative-europeenne-et-globale?lang=fr. Acesso 30 jun 2016.
É esse movimento que impulsiona a concorrência normativa, ou seja, a competição velada em que se inserem os Estados em nível global ou regional para tornar seu direito mais atrativo ou favorável, tanto no campo normativo como no campo judicial, para a instalação de empresas transnacionais. Isso faz com que, no contexto de caos jurídico, outros fenômenos que se destaquem sejam os da desregulação competitiva e dos mercados de direitos nacionais.

A aceleração, portanto, no campo da globalização econômica, influencia enormemente a estruturação, ainda caótica e confusa de um direito transnacional que pouco se caracteriza por tentativas de desenvolvimento de um direito global no sentido da criação de uma ordem jurídica mundial, mas de um mercado global de direitos nacionais somados a normas de cariz internacional de viés público e privado ${ }^{31}$. Nesse cenário o direito privado se politiza e se publiciza e o direito público se privatiza, a partir da existência de normas com caráter e abrangência públicos, porém produzidos por atores privados em uma modalidade de deslocalização normativa $^{32}$.

É nesse cenário que emerge a ideia de uma governança por números, em que as regras jurídicas abarcadas pelo ideal de um governo por leis e com ênfase no poder legislativo dos Estados concorre e aos poucos vai sendo suplantado por uma governança por números, marcada pela auto-regulação das sociedades e pelo ideal estatístico de quantificação e programação de comportamentos $^{33}$. Isso pode ser visualizado pelo crescente uso de rankings e indicadores para a realização de avaliações em relação a países e aos sistemas de justiça nacionais, bem como pela crescente noção de que a normatividade perde sua dimensão vertical, na medida em que a norma se afasta da lógica dedutiva - de ser genérica e abstrata para abarcar os fatos da vida - aproximando-se da perspectiva indutiva - de partir de fatos já dados para criar legislações "programação", como é o caso do TIS A que se verá a seguir.

31 FRYDMAN, Benôit. La concurrence normative européenne et globale. Bruxelas: Centre Perelman de Philosophie du droit, 2016. Disponível em: http:/ / www.philodroit.be/La-concurrence-normative-europeenne-et-globale?lang=fr. Acesso 30 jun 2016.

32 DELMAS-MARTY, Mireille. Les forces imaginantes du droit (III): La Refondation des Pouvoirs. Paris: Seuil, 2007.

33 SUPIOT, Alain. O Espirito de Filadélfia. A justiça social diante do mercado total. Tradução de Tânia do Valle Tschiedel. Porto Alegre: Sulina, 2014, p.70. 


\section{DA FORÇA DA REALIDADE: TISA E A GOVERNANÇA POR NÚMEROS.}

Alain Supiot ${ }^{34}$ afirma que o direito, assim como a técnica, a religião ou as artes é um fato da cultura, ou seja, um elemento que se insere na representação de mundo que domina determinada época. Sob essa perspectiva, em todo e qualquer momento da história, a força das coisas pode de engendrar situações capazes de alterar elementos no campo das ideias. Nesse sentido, um dos grandes exemplos dessa situação é a emergência, em meados da década de 1970 e início da década de 1980, do paradigma ultraliberal.

Este impulsiona a aceleração econômica mundial, com o crescimento do número de empresas transnacionais e de seu poder no cenário internacional frente a medidas de implantação de um Estado Mínimo diante das perspectivas de um Mercado Total. Esse é o ponto em que a força da realidade revelada pelas modificações sociais, políticas e econômicas passa a realizar mudanças no campo jurídico.

Assim, o tradicional, ocidental e moderno governo por leis passa a conviver e aos poucos ser ameaçado pela ideia da governança por números e por modelos empresariais para a gestão da esfera pública, com utilização de objetos normativos não clássicos como é o caso dos rankings, indicadores, metas e normas técnicas e de gestão, os quais passam a ser parâmetros para interferir nos sistemas jurídicos nacionais a fim de provocar processos de privatização e desregulamentação de atividades. Um exemplo do resultado do modelo de governança por números é o TIS $A$, acordo desenvolvido a portas fechadas com a participação de países com grandes esferas de poder político e econômico em nível global e empresas transnacionais com a finalidade de estabelecer regramentos acerca da utilização de comércio de serviços em âmbito mundial.

\subsection{Legislação "programação" e os efeitos da governança por números.}

Governo e direito são categorias que, embora não tenham sido propriamente criadas na modernidade, sofrem várias influências do racionalismo moderno de forma que, diante dos baluartes nacionais da moderni-

34 SUPIOT, Alain. La Gowvernance par les nombres. Nantes: Fayard: Poids et mesures du monde, 2015. dade, mesmo com as vicissitudes da mundialização tornou-se complexo compreender essas categorias longe da visão de Estado e de miradas nacionais ${ }^{35}$.

Segundo Alain Supiot ${ }^{36}$, reduzir governo a exercício do poder é uma característica típica da modernidade. Assim, afasta-se deste uma dimensão real de estética da representatividade para ser visto como um instrumento de dominação, como uma grande máquina regida pelo paradigma mecanicista, permeada de jogos, pesos e contrapesos. A despeito dessa estrutura, a noção de governo implica a relação entre governantes e governados, de modo que as leis produzidas são vistas como referências normativas comuns tanto para governados quanto para governantes.

Assim, tanto sob a estrutura de um Estado liberal quanto na de um Estado social, a lógica de um governo sob tal molde engendra sua legitimidade na organização jurídica para reger as relações internas e internacionais. O racionalismo moderno se reflete no sonho da harmonia pelo cálculo no sentido de aproximar o direito das ciências matemática com o escopo de validar o próprio direito, dando-lhe caráter científico ao regrar as condutas do campo do dever ser.

O método do direito de um governo por leis, dessa forma, seguiria a lógica dedutiva de, conforme já fora explanado, a partir de situações gerais elaborar normas abstratas capazes de regular um sem número de situações específicas. Todavia a onda ultraliberal, desenvolvida em meados da década de 1970, parte de uma lógica indutiva $^{37}$, ao observar situações e casos específicos a fim de desenvolver um sem número de regras e normas. Essa é uma das diferenças entre governo por leis e governança por números.

Segundo Alain Supiot ${ }^{38}$, a governança ${ }^{39}$ pelos núme-

35 BECK, Ulrich. La mirada cosmopolita o guerra es la pa\%: Traduccion de Bernardo Moreno Carillo. Barcelona: Paidós, 2005.

36 SUPIOT, Alain. La Gouvernance par les nombres. Nantes: Fayard: Poids et mesures du monde, 2015.

37 SUPIOT, Alain. O Espirito de Filadélfia. A justiça social diante do mercado total. Tradução de Tânia do Valle Tschiedel. Porto Alegre: Sulina, 2014, p. 71.

38 SUPIOT, Alain. O Espírito de Filadélfia. A justiça social diante do mercado total. Tradução de Tânia do Valle Tschiedel. Porto Alegre: Sulina, 2014, p. 70.

39 Essa noção aproxima-se da ideia de governança apresentada por Salem Hikmat Nasser. Segundo ele, a noção de governança como significando os modos pelos quais a sociedade é regulada compreende o direito. Todavia, frequentemente. a ênfase na governança como categoria privilegiada é usada para indicar que o direito tem um papel na regulação da vida em sociedade que se encolhe progressivamente, perdendo espaço para outros tipos de meios ou 
ros se apoia em operações de quantificação e de programação, por meio de técnicas de análise comparativa de comportamentos dos atores internacionais. Essas operações acabam possuindo relevância a ponto de ou se tornarem efetivamente normas jurídicas ou influenciarem drasticamente os ordenamentos jurídicos nos mais diversos níveis. Justamente em razão dessa situação, duas das principais características de uma governança por números são a concorrência normativa e a deslocalização normativa e judiciária.

A crise do paradigma racionalista é substituída por ideais de eficiência e produtividade em prol de razões do mercado, fomentando um processo de desarticulação de poderes no seio das instituições nacionais e fragmentação em âmbito internacional, com o crescimento vertiginoso do poder de entidades privadas. Nesse sentido, Mireille Delmas-Marty ${ }^{40}$ afirma que a mundialização econômica não garante qualquer legitimidade democrática aos processos ocorridos tanto dentro quanto fora do âmbito dos Estados, principalmente pelo fato de que a ciência e a tecnologia são, na estrutura de uma governança por números, introduzidas no conjunto normativo nacional e internacional, deixando de serem objetos aleatórios ou adjacentes para se tornarem centrais na esfera política.

Isso é comprovado por meio da grande força que os especialistas possuem na estrutura de uma governança por números. No século XXI, a vulnerabilidade se dá pelo desconhecimento de questões técnicas específicas em relação a temas complexos, como tecnologia ${ }^{41} \mathrm{e}$ cibernética $^{42}$, por exemplo. Assim, poucos especialistas

instrumentos regulatórios. NASSER, Salem Hikmat. Direito Global em pedaços: Fragmentação, Regimes e Pluralismo. In: Revista de Direito Internacional - Brazilian Journal of International Law. Vol. 12, $\mathrm{n}^{\circ} 2$, 2015. Disponível em: http://www.publicacoesacademicas.uniceub. br/index.php/rdi/article/view/3707/pdf. Acesso em 14 jul 2016.

40 DELMAS-MARTY, Mireille. Les forces imaginantes du droit (III): La Refondation des Pouvoirs. Paris: Seuil, 2007, p. 28.

41 Sobre a relação da tecnologia, cidadania e direitos humanos veja-se: LIMBERGER, Têmis. SALDANHA, Jânia Maria Lopes. Cibercidadania no mundo globalizado: o desafio das novas tecnologias e a concretização dos direitos humanos nas democracias contemporâneas. Anuário de Derecho constitucional latinoamericano. Ano XVIII. Bogotá: Fundación Adenauer, 2012, p. 215-230. Sobre a relação da tecnologia com as vulnerabilidades trazidas pelo risco de controle total em ambiente virtual, veja-se: SALDANHA, Jânia Maria Lopes; BRUM, Márcio Morais; MELLO, Rafaela da Cruz. As novas tecnologias da informação e comunicação entre a promessa de liberdade e o risco de controle total: estudo da jurisprudência do sistema interamericano de direitos humanos. In: Anuario mexicano de Derecho Internacional. Vol. XVI. Jan/Dez. 2016. p. 461-498. 42 SALDANHA, Jânia Maria Lopes. Os desafios do "Império desenvolvem muitas regras que adquirem força de leis em razão das exigências, sobretudo de mercado, sem que haja qualquer processo democrático a fim de discutir a pertinência desse regramento e sua influência para indivíduos e para a coletividade.

Um dos exemplos dessa situação são relatórios como o Doing Bussiness ${ }^{43}$. Esse relatório periódico realizado por especialistas do Banco Mundial apresenta índices nas mais diversas variáveis a fim de classificar diferentes países do mundo. Essa classificação ocorre, sobretudo, com a finalidade de atender a demandas empresariais, ou seja, a partir da observação do relatório, empresas transnacionais são capazes de avaliar quais são os países que oferecem maiores vantagens para sua instalação e, essas vantagens podem ser tanto em questões de flexibilização trabalhista, como por meio de incentivos fiscais ou ainda facilidades em relação a procedimentos de licença ou licenciamento ambientais.

Tal situação demonstra uma das principais características de uma governança por números: a influência de standards e indicadores no procedimento de fragmentação de normas jurídicas já existentes ou construção de novas regras. Esses elementos são apresentados por Benôit Frydman ${ }^{44}$ como objetos normativos não identificados (O.N.N.I) justamente em função da dificuldade em ligar sua natureza à proporção de seus efeitos e desafiam os juristas em razão da diversidade de fontes, dos efeitos e da aparência arbitrária de suas combinações.

As normas técnicas e de gestão (standards e indicadores) quanto à sua elaboração não são frutos de procedimento parlamentar ou de instituições públicas representativas, mas emergem da prática, de conhecimentos de especialistas e técnicos sobre determinados assuntos. Segundo Jânia Saldanha ${ }^{45}$, as normas técnicas prestam-se a especificar produtos em nome das políticas de qualidade total ou de "defeito zero", configurando-se como

Cibernético" na era da aceleração e da informação: Um "sexto" continente de liberdade perfeita ou de controle perfeito. In: TYBUSCH, Jerônimo et al (org). Direitos Emergentes na sociedade globa: Anuário do Programa de Pós-Graduação em Direito da UFSM. Ijuí: Editora Unijuí, 2013, p. 173-220.

43 GRUPO BANCO MUNDIAL. Doing Business. Disponível em: http://portugues.doingbusiness.org/. Acesso em 01 jul 2016.

44 FRYDMAN, Benoit. Prendre les standards et les indicateus au sérieux. In FRYDMAN, Benoit et VAN WAEYENBERGE, Arnaud [coord]. Governer par les standars et les indicateus: De Hume aux rankings. Bruxelles: Bruylant, 2014.

45 SALDANHA, Jânia. Cosmopolis. Edizioni Classi. Firenzi, Parigi, Porto Alegre, 2016, p. 275. 
regramentos indispensáveis para o funcionamento da economia na atualidade ${ }^{46}$. Da mesma forma, as normas de gestão aplicam-se ao campo da gerência e da organização de condutas humanas em busca de qualidade e eficiência.

Ainda conforme Jânia Saldanha ${ }^{47}$ o século XXI vem acompanhado de uma sofisticação das normas procedimentais de forma global. Dessa maneira, as normas técnicas e de gestão apresentam-se no conjunto de normas procedimentais que indicam a vitória da performatividade sobre as regras, estrutura típica dos pensamentos ultraliberais.

Assim, enquanto na estrutura de um governo por leis o legislador possuía elevada distinção, no panorama de uma governança por números, esses elementos normativos não identificados e seus produtores, os técnicos e especialistas em determinadas áreas possuem relevân$\mathrm{Cia}^{48}$, de modo que essas novas normas mesmo possuindo cariz organizacional, ou se elevam ao patamar de normas jurídicas ou modificam substancialmente essas, contribuindo para a esfera híbrida e de caos jurídico do direito na atualidade.

A produção legislativa nos mais diferentes níveis acaba por ser afetada por constatações vindas desses índices e dessas normas procedimentais. Isso é o que demonstra o processo de concorrência normativa dito anteriormente. Segundo Benôit Frydman ${ }^{49}$ dois são os tipos de reação dos Estados diante da inexorável reali-

46 Como exemplo desse tipo de norma pode-se destacar o conjunto de normas ISSO, como a ISSO 9000 e a ISSO 14000, ambas em matéria ambiental.

47 SALDANHA, Jânia. Cosmopolis. Edizioni Classi. Firenzi, Parigi, Porto Alegre, 2016, p. 273.

48 Da mesma forma, os referidos O.N.N.I não são publicados em órgãos oficiais, mas possuem uma espécie de rótulo, que demonstra a outros atores internacionais e nacionais que houve adesão e engajamento no respeito de norma X ou Y. É o que aconteceu, por exemplo, com as Diretrizes "Nova Abordagem e Abordagem Global", advindas da criação do mercado interno europeu em 1992, e que se referem à regulamentação dos produtos e avaliação da conformidade destes, limitando a intervenção governamental ao essencial e adotando a Marcação CE para facilitar a circulação de mercadorias entre os Estados-Membros da União Europeia. Essas normas não foram publicadas em veículos oficiais, entretanto possuem um enorme espectro de atuação e conferem obrigatoriedade àqueles que participam da produção de produtos na União Europeia, podendo inclusive gerar ações judiciais e eventuais sanções por descumprimento.

49 FRYDMAN, Benôit. La concurrence normative européenne et globale. Bruxelas: Centre Perelman de Philosophie du droit, 2016. Disponível em: http:/ / www.philodroit.be/La-concurrence-normative-europeenne-et-globale?lang=fr. Acesso 30 jun 2016. dade de concorrência: adotam medidas defensivas tanto no campo político quanto jurídico a fim de se prevenirem dos efeitos nefastos da escolha do direito pelos destinatários (em geral empresas transnacionais) ou optam pela adoção de medidas ofensivas, através das quais os Estados adaptam o seu direito a fim de torná-lo mais atrativo.

Dessa maneira, Benôit Frydman ${ }^{50}$ assevera que os indicadores e os standards têm por função anunciada conceder informações aos operadores econômicos e financeiros a fim de lhes permitir participar de um jogo de concorrências e auxiliar em decisões referentes a investimentos. Todavia, a realidade é que eles substituem uma função de governança e de disciplina dos Estados e governos, em que as performances são julgadas tanto no plano internacional quanto interno.

Isso não deixa de ser um gerenciamento dos Estados através do mecanismo dos indicadores que são disposições normativas em um ambiente não soberano. Assim, os indicadores, influenciados enormemente pelo sonho da harmonia pelo cálculo estatístico, são peças chaves para o desenvolvimento de uma governança por números. Nesse sentido, David Restrepo Amariles ${ }^{51}$ afirma que os objetos normativos não identificados como os standards e os indicadores são a tecnologia da governança global, ferramentas pelas quais o poder é exercido com e para além dos Estados.

Dessa forma, essa lógica da governança por números enseja dois tipos de fenômenos: a alteração de normas e de procedimentos jurídicos já existentes no âmbito dos Estados e da sociedade internacional e/ou a criação de legislações ou tratados que tenham como norte o mínimo de regulação para atividades empresariais. Dentro do primeiro tipo de fenômeno, Benôit Frydman destaca que segundo o relatório de 2015 do Banco Mundial, desde 2004, os Estados realizaram o total de 2400 reformas internas em suas legislações a fim de tornar suas ordens jurídicas mais atrativas a investidores estrangeiros. Assim, segundo ele:

(...) somente no período de um ano, de junho de 2013 a junho de 2014, 230 reformas legislativas

50 FRYDMAN, Benôit. La concurrence normative européenne et globale. Bruxelas: Centre Perelman de Philosophie du droit, 2016. Disponível em: http:/ / www.philodroit.be/La-concurrence-normative-europeenne-et-globale?lang=fr. Acesso 30 jun 2016.

51 AMARILES, David Restrepo. Special Issue on Legal Indicators, Global Law and Legal Pluralism. In: The Journal of Legal Pluralism. Vol. 47, nº.1, 2015. 
ou regulamentares foram registradas em 123 jurisdições. Entre elas, os Estados da Europa e da Ásia central destacam-se com $85 \%$ de Estados que procederam reformas neste ano. Mais de 50 Estados organizaram comissões especiais de reforma com vistas a melhorar sua posição na classificação dos rankings do Banco Mundial e alguns deles não hesitaram em divulgar suas performances em campanhas de publicidade ${ }^{52}$.

É no segundo tipo de fenômeno, no entanto, que se enquadra o acordo que será objeto de análise breve na sequência desse texto, o Acordo sobre Comércio de Serviços, conhecido como TIS A, no qual alguns Estados, sob a influência e lobby de empresas transnacionais estão, às escuras, realizando tratativas no intuito de privatizar e desregulamentar questões vinculadas ao comércio internacional de serviços. Com base, ainda, nas poucas informações sobre as tratativas, pode-se inferir que a lógica de mercado e de naturalização do direito econômico permeia as negociações, de modo que, tentar-se-á demonstrar, neste artigo, que esse acordo pode ser compreendido enquanto manifestação do processo de governança por números.

\subsection{TISA como demonstração da força das coisas e da realidade de uma governança por números}

$\mathrm{Na}$ estética do caos que domina não só a paisagem jurídica em nível global, mas também as esferas econômica e política, o crescimento dos ideais ultraliberais passaram a ser observados no espectro considerável de tratados de livre comércio, acordos bi e multilaterais entre os mais diversos países versando sobre questões econômicas e fiscais, bem como pelo uso em maior escala de indicadores e standards, que são elementos basilares de uma governança por números para avaliar os sistemas jurídicos nos mais diferentes níveis.

É nesse contexto que surge a ideia do Acordo sobre Comércio de Serviços, mais conhecido por sua sigla em inglês TIS $A$. Esse tratado, juntamente a outros como o Tratado Transpacífico (TPP) e o Tratado Transatlântico (TTTP) estabelece não só a hegemonia dos interesses de empresas transnacionais em um contexto de neoliberalismo como corrobora a premissa de concorrência

52 FRYDMAN, Benôit. La concurrence normative européenne et globale. Bruxelas: Centre Perelman de Philosophie du droit, 2016. Disponível em: http:/ / www.philodroit.be/La-concurrence-normative-europeenne-et-globale?lang=fr. Acesso 30 jun 2016. normativa seguida de tentativas de suplantação progressiva de um governo por leis por uma governança por números.

Para que se compreenda essa premissa, é necessário explicar em que consiste o TISA. As negociações em torno desse acordo começaram a se desenvolver em 2012 e hoje contam com a participação de 23 países-membros da Organização Mundial do Comércio (OMC) juntamente a países da União Europeia ${ }^{53}$ e, sinteticamente, tratam da abertura, em âmbito global do comércio de serviços entre os Estados participantes.

A justificativa oficial ${ }^{54}$ existente é a de que na ordem globalizada atual, os serviços possuem importância cada vez maior na economia internacional e configuram-se como essenciais para grande parte dos países do mundo, sendo, portanto, necessária a abertura do comércio desses serviços em larga escala a fim de romper com obstáculos como as limitações nacionais de tratamento ${ }^{55}$ e as limitações ao acesso aos mercados. Segundo informações oficiais ${ }^{56}$, as negociações iniciais abarcam todos os tipos de serviços à exceção de serviços que só o Estado é capaz de prestar, como é o caso da justiça.

Diante disso surge a afirmação de Zizek ${ }^{57}$ de que o referido acordo se configurará como a espinha dorsal jurídica para a reestruturação do mercado mundial,

53 Consoante dados oficiais obtidos no site da União Europeia, além dos países-membros do bloco (incluindo o Reino Unido que recentemente em plebiscito votou pela saída do bloco europeu), os seguintes Estados fazem parte das tratativas para o acordo: Austrália, Canadá, Colômbia, Coreia do Sul, Costa Rica, Chile, Estados Unidos, Hong Kong, Islândia, Israel, Japão, Liechtenstein, Mauricio, México, Noruega, Nova Zelândia, Paquistão, Panamá, Paraguai, Peru, Suíça, Taiwan e Turquia.

54 Uma das justificativas oficiais encontradas para o tratado em comento encontra-se no site da Comissão Europeia, disponível no seguinte link: http://ec.europa.eu/trade/policy/in-focus/tisa/ questions-and-answers/index_es.htm. Acesso 04 jul 2016.

55 Consoante explicações concedidas pela Comissão Europeia, as limitações nacionais de tratamento consistem no ato de dar aos investidores estrangeiros um tratamento diferente dos que recebem os investidores nacionais (é o que ocorre, por exemplo, quando um país somente permite a prestação de serviços de telecomunicações a empresas pertencentes a seus próprios cidadãos. As limitações de acesso ao mercado, por sua vez, consistem em limitar o nível de atividade dos investidores estrangeiros.

56 Uma das justificativas oficiais encontradas para o tratado em comento encontra-se no site da Comissão Europeia, disponível no seguinte link: http://ec.europa.eu/trade/policy/in-focus/tisa/ questions-and-answers/index_es.htm. Acesso 04 jul 2016.

57 ŽIŽEK, Slavoj. How capital captured politics. In: The Guardian. 13 de Julho de 2014. Disponível em: https://www.theguardian.com/commentisfree/2014/jul/13/capital-politics-wikileaksdemocracy-market-freedom. Acesso 05 jul 2016. 
seguindo princípios de ordem ultraliberal. Isto porque, embora a explicação formal seja a de regular a abertura do comércio de serviços, a força das coisas revela a realidade das pretensões de privatização de serviços públicos e desregulamentação em relação às atividades de empresas transnacionais, como é o caso da Walmart ou de FedEx ${ }^{58}$.

Consoante o relatório "El Acuerdo de los Auténticos Buenos Amigos de las Empresas Transnacionales", publicado em 2014, a ideia de elaborar um Acordo sobre Comércio de Serviços partiu de experts comerciais, grupos de pressão e lobbys de empresas transnacionais insatisfeitas com o ritmo das negociações sobre serviços no âmbito da OMC. Isso somado a ondas ultraliberais provenientes de um ambiente de crise econômica fomentou a ideia de elaboração do TIS $A$, o qual ainda não se converteu em acordo no âmbito da OMC, já que neste patamar continua vigente, desde 1995, o Acordo Geral sobre o Comércio de Serviços (AGCS).

O objetivo do TIS $A$ é de radicalizar as proposições já existentes no ACGS. E essa radicalização tem como pressuposto a modificação ou a eliminação de regulamentações nacionais com o objetivo de facilitar as trocas de serviços no mercado mundial ${ }^{59}$. As condições, para a concorrência, passariam a ser dadas pelo próprio mercado e não pelos Estados.

Prova disso se encontra no documento disponibilizado no site Wikileaks com o teor da $\sigma^{a}$ rodada de

58 Conforme o relatório "El Acuerdo de los Auténticos Buenos Amigos de las Empresas Transnacionales", a transnacional Walmart adotou a posição de defesa da proibição de legislação interna dos países que possuam regras rígidas acerca de venda de bebidas alcóolicas, tamanho e horário de funcionamento de lojas. A empresa FedEX, por sua vez, manifestou que espera que o TIS $A$ elimine as regulamentações que favorecem aos serviços públicos postais, elimine as regras acerca de licenças para provedores de serviços de entrega urgente e elimine regras que obrigam aos provedores de serviços de entrega urgente a contribuir com fundos de serviços universais. GOULD, Ellen. El Acuerdo de los Auténticos Buenos Amigos de las Empresas Transnacionales. Setembro de 2014. Disponível em: http://www.world-psi.org/sites/default/files/esp_el_acuerdo_de_ los_autenticos_buenos_amigos_report_tisa.pdf. Acesso em 10 jun 2016. 59 Importante salientar que o texto do tratado, até a elaboração desse trabalho, não havia sido finalizado, de modo que as rodadas de discussão e de negociação de cláusulas, ainda, estavam ocorrendo e os documentos oriundos dessas discussões, mantidos em sigilo. Todavia, o site Wikileaks, desde 03 de junho de 2015, começou a disponibilizar trechos do teor das discussões entre os países, de modo que tais trechos, em conjunto com relatórios e textos científicos embasaram a elaboração deste trabalho. Assim, no que se refere ao material do Wikileaks, observou-se o teor de 22 documentos, dando-se ênfase para os concernentes à transparência, serviços de entrega e regulamentação doméstica. negociações sobre o TISA, ocorrida em $2014^{60}$. Nessa rodada, o texto preliminar do artigo $1^{\circ}$ do acordo apresentava a ideia de que os Estados deveriam se transformar em instituições mais transparentes para os atores comerciais globais, com o intuito de que estes pudessem averiguar riscos e possibilidades em relação a investimentos em determinados Estados. Tal premissa reflete duas das lógicas da governança por números: a presença de indicadores e índices para que as empresas possam determinar o grau de inserção e comprometimento dos países com as regras desse acordo e o fomento da internormatividade, a partir do momento em que um acordo internacional com forte influência de empresas é capaz de ensejar mudanças nas estruturas jurídicas internas dos países a fim de lhes deixá-los mais competitivos.

Dentre os muitos perigos desse acordo, o principal deles é a sua realização longe de qualquer cariz democrático. As tratativas vêm sendo realizadas a portas fechadas entre os Estados e sob o lobby das empresas, de modo que o conhecimento que se tem sobre esse hoje é por meio de informações oficiais esparsas, relatórios que abordam pontos polêmicos sobre temas que já foram divulgados ou por vazamentos que ocorreram por meio do Wikileakes ${ }^{61}$. A transparência ainda é posta em xeque pelas informações que se tem de que há cláusulas do acordo que permanecerão em sigilo, sem publicização por no mínimo cinco anos a contar da assinatura do $\operatorname{acordo}^{62}$.

Além das afrontas diretas à democracia, a noção de interesse geral das sociedades é vista meramente pela soma de alguns interesses particulares. Como bem refere o relatório anteriormente referido ${ }^{63}$, os acordos de investimento e de comércio atuais não tem tanto relação com a eliminação de tarifas para a circulação de mercadorias e serviços, mas possuem vinculação com

60 TISA, Anexo sobre Transparência. Disponível em: https:// wikileaks.org/tisa/document/20140416_Annex-on-Transparency/20140416_Annex-on-Transparency.pdf. Acesso 05 jul 2016.

61 ŽIŽEK, Slavoj. How capital captured politics. In: The Guardian. 13 de Julho de 2014. Disponível em: https://www.theguardian.com/commentisfree/2014/jul/13/capital-politics-wikileaksdemocracy-market-freedom. Acesso 05 jul 2016.

62 GOULD, Ellen. El Acuerdo de los Auténticos Buenos Amigos de las Empresas Transnacionales. Setembro de 2014. Disponível em: http:// www.world-psi.org/sites/default/files/esp_el_acuerdo_de_los_autenticos_buenos_amigos_report_tisa.pdf. Acesso em 10 jun 2016. 63 GOULD, Ellen. El Acuerdo de los Auténticos Buenos Amigos de las Empresas Transnacionales. Setembro de 2014. Disponível em: http:// www.world-psi.org/sites/default/files/esp_el_acuerdo_de_los_autenticos_buenos_amigos_report_tisa.pdf. Acesso em 10 jun 2016. 
restrições a políticas que os Estados por meio de seus governos possam implementar. Dessa forma, as transnacionais hoje manifestam suas inquietudes em temas como cargas diferentes em matéria de regulamentação, influência e controle de governos em questões de mercado e restrições em relação a fluxos de informações em escala nacional e global.

No campo específico da prestação de serviços, o interesse é duplo: privatizar serviços prestados pelos Estados, como saúde, energia, educação, saneamento básico, dentre outros e exigir a desregulamentação estatal em relação a serviços já prestados por entes privados. Um dos exemplos da desregulamentação é apresentado no relatório ${ }^{64}$ pela descrição da empresa Walmart que teria defendido a posição de que o TIS $A$ deveria proibir as restrições nacionais não só em relação ao tamanho e ao horário de funcionamento de lojas, mas também em matéria de localização geográfica das lojas, que atenta diretamente contra as faculdades de zoneamento urbano que é de competência de governos locais.

Além desse exemplo, questões específicas comprovam que o acordo nasce sob a égide de uma governança por números e de imposição de interesses de mercado sobre ordens democráticas consolidadas. Uma dessas questões é a presença de algumas cláusulas perigosas no acordo como é o caso da cláusula de "trinquete", da cláusula de manutenção do status quo e do regime de top down $n^{65}$. A primeira dessas cláusulas prevê que um país não pode reintroduzir um obstáculo ao comércio já eliminado, possibilitando tornar perene e permanente qualquer experimento de desregulamentação sem possibilidade de reverter a situação.

Da mesma forma, no procedimento de manutenção do status quo uma vez que determinado governo de um Estado privatize certo serviço ou o desregulamente o governo sucessor será impossibilitado de rever essa situação. As políticas vigentes no momento do acordo serão perpetuadas no sentido de favorecer aos interesses do mercado. O regime de top down vincula-se não só à

64 GOULD, Ellen. El Acuerdo de los Auténticos Buenos Amigos de las Empresas Transnacionales. Setembro de 2014. Disponível em: http:// www.world-psi.org/sites/default/files/esp_el_acuerdo_de_los_autenticos_buenos_amigos_report_tisa.pdf. Acesso em 10 jun 2016. 65 ADLUNG, Rudolf. MAMDOUH, Hamid. How To Design Trade Agreements In Services: Top Down Or Bottom Up? Documento de la OMC ERSD-2013-08, 18 de junio de 2013. Disponível em: https:/ / www.wto.org/english/res_e/reser_e/ersd201308_e.pdf. Acesso 11 jul 2016. impossibilidade de reestatização de serviços públicos já privatizados como impõe a aplicação vertical de mecanismos para que os governos submetam a maior quantidade possível de serviços ao TIS $A^{66}$.

Nesse ponto inclui-se outra prerrogativa do acordo que é a das listas negativas e da garantia da cláusula para o futuro. Em geral os acordos comerciais operam sob a lógica de listas positivas. Dessa maneira, sob essa lógica, em um acordo comercial, os Estados apresentariam listas com os serviços que gostariam que estivessem regulados pelo tratado. No entanto, a lógica do TIS A é a de operar com listas negativas em que os Estados expõem os serviços que não gostariam de dispor para apreciação e negociação juntamente ao tratado e todos os demais passam a ser abarcados neste.

Essa lógica já serve como fundamento para a garantia de cláusula para o futuro, no momento em que todo e qualquer novo serviço que se torne comercializável como resultado da inovação técnica e tecnológica possa ser provida, internacionalmente, sem a necessidade de eventuais negociações adicionais. Assim, os Estados ficam inviabilizados de decidir se desejam ou não explorar tal serviço, uma vez que ele já recai sob o domínio do $\operatorname{TIS} A$.

Todas essas normas surgem com a finalidade de evitar qualquer fomento à indústria nacional de determinado Estado. As transnacionais, embora sejam economicamente mais pujantes quando comparadas com indústrias e serviços locais, por meio do TIS $A$ possuem condições legitimadas por meio de um acordo e, portanto com respaldo jurídico, para agir em paridade de condições em relação a qualquer forma de prestação de serviço nacional. E, sob esse aspecto, a lógica de governança por números, por meio da lógica indutiva de inferir a norma da medida dos fatos, que as controvérsias de direito, prioritariamente, não serão resolvidas em tribunais internacionais ou nacionais, mas por meio de painéis arbitrais independentes, seguindo a lógica da arbitragem já adotada nas controvérsias econômicas da OMC.

Por fim, no intuito de comprovar que o TIS $A$ se insere no contexto de uma governança por números encontra-se a prerrogativa de que neste acordo há a

66 GOULD, Ellen. El Acuerdo de los Auténticos Buenos Amigos de las Empresas Transnacionales. Setembro de 2014. Disponível em: http:// www.world-psi.org/sites/default/files/esp_el_acuerdo_de_los_autenticos_buenos_amigos_report_tisa.pdf. Acesso em 10 jun 2016. 
cláusula que permite que qualquer Estado membro ou qualquer empresa seja capaz de contestar uma lei nacional ou uma política pública proveniente dos Estados sob a alegação de que esta prejudica a livre concorrência que o tratado garante ${ }^{67}$. Essa denúncia não será avaliada por qualquer esfera institucional do país denunciado, mas sim pelos painéis independentes que atuam sob a lógica de soluções arbitrais.

\section{Considerações finais}

Mireille Delmas-Marty afirma que o contexto de crise em que se vive na mundialização demonstra que a força das coisas acaba revelando a incompletude de muitas ideias. Na estética do caos, as crises, radicalizações e rupturas, mais do que a incompletude das ideias, desvelam um vazio ou mais exatamente a ausência de um modelo teórico claro capaz de representar as práticas globais e de conduzir minimamente à reorganização dos poderes.

O despontar do século XXI exacerbou concepções da modernidade e, ao mesmo tempo promoveu o rompimento radical com outros elementos desse período, de modo que, diante do caos da paisagem global atual, (re)indagar conceitos deve ser uma tarefa constante. $\mathrm{O}$ direito passa a ser um exemplo de conjunto de estruturas a serem indagadas frente ao surgimento e consolidação de relações transnacionais. As concepções clássicas de direito e de um governo por leis passam a ser débeis para explicar as fragilidades e porosidades da atual arquitetura social, com sua pluralidade de atores.

Vive-se em um processo global profundo de transformações das formas, dos processos de regulação e, principalmente da própria natureza das regras jurídicas que se desenvolve em conjunto com a expansão de novos tipos de normatividade. Esse cenário é propício para o desenvolvimento e crescimento da estrutura de uma governança por números, e, que normas procedimentais passam a concorrer, modificar ou até mesmo suplantar normas jurídicas clássicas, fomentando fenômenos como os da internormatividade, da desregulamentação jurídica e de sujeição legal aos interesses de mercado.

67 GOULD, Ellen. El Acuerdo de los Auténticos Buenos Amigos de las Empresas Transnacionales. Setembro de 2014. Disponível em: http:// www.world-psi.org/sites/default/files/esp_el_acuerdo_de_los_autenticos_buenos_amigos_report_tisa.pdf. Acesso em 10 jun 2016.
A lógica ultraliberal, com seus vieses neoliberal e neoconservador, apresenta a naturalização do direito econômico e, com isso, índices, metas, rankings e demais elementos de classificação e medida de desempenho passam a ser a base para a elaboração das regras de direito a fim de beneficiar empresas e grupos transnacionais. Essa é não só a base da concorrência normativa entre Estados, como também é a base de alguns acordos de livre comércio atuais, como é o caso do TIS A. Dessa maneira, indubitável a afirmação de que o TIS $A$ com suas disposições obscuras. Porém, já polêmicas, uma vez que afrontam normas produzidas, democraticamente, no seio dos Estados, insere-se nesse panorama de caos jurídico e de concorrência/passagem de um moderno governo por leis para uma perigosa e com efeitos ainda desconhecidos governança por números.

\section{REFERÊNCIAS BIBLIOGRÁFICAS}

ADLUNG, Rudolf. MAMDOUH, Hamid. How To Design Trade Agreements In Services: Top Down Or Bottom Up? Documento de la OMC ERSD-2013-08, 18 de junio de 2013. Disponível em: https://www.wto.org/ english/res_e/reser_e/ersd201308_e.pdf. Acesso 11 jul 2016.

AMARILES, David Restrepo. Special Issue on Legal Indicators, Global Law and Legal Pluralism. In: The Journal of Legal Pluralism. Vol. 47, nº.1, 2015.

BECK, Ulrich. La mirada cosmopolita o guerra es la paz: Traduccion de Bernardo Moreno Carillo. Barcelona: Paidós, 2005.

CHEVALLIER, Jacques. O Estado Pós-Moderno. Tradução de Marçal Justen Filho. Belo Horizonte: Fórum, 2009.

DELMAS-MARTY, Mireille. Três desafios para um Direito Mundial. Tradução Fauzi Hassan Choukr. Rio de Janeiro: Lúmen Júris, 2003.

Les forces imaginantes du droit: Le relatif et l'universel. Paris. Seuil. 2004.

. Les forces imaginantes du droit (II): Le pluralism ordonné. Paris. Seuil. 2006.

Les forces imaginantes du droit (III): La Refondation des Pouvoirs. Paris: Seuil, 2007.

EUROPEAN COMISSION. Perguntas y respuestas. Di- 
sponível em: http://ec.europa.eu/trade/policy/in-focus/tisa/questions-and-answers/index_es.htm. Acesso 04 jul 2016.

FRYDMAN, Benôit. Citoyen, Droit \& Societé: Les transformations du droit moderne. Bruxelas: Fundación Roi Baudouin, 1998.

. Prendre les standards et les indicateus au sérieux. In FRYDMAN, Benoit et VAN WAEYENBERGE, Arnaud [coord]. Governer par les standars et les indicateus: De Hume aux rankings. Bruxelles: Bruylant, 2014.

La concurrence normative européenne et globale. Bruxelas: Centre Perelman de Philosophie du droit, 2016. Disponível em: http://www.philodroit.be/La-concurrence-normative-europeenne-etglobale?lang=fr. Acesso 30 jun 2016.

GOULD, Ellen. El Acuerdo de los Auténticos Buenos Amigos de las Empresas Transnacionales. Setembro de 2014. Disponível em: http://www.world-psi.org/sites/default/ files/esp_el_acuerdo_de_los_autenticos_buenos_amigos_report_tisa.pdf. Acesso em 10 jun 2016.

GRUPO BANCO MUNDIAL. Doing Business. Disponível em: http://portugues.doingbusiness.org/. Acesso em 01 jul 2016.

ISAIA, Cristiano Becker. Processo civil e hermenêutica: crise do procedimento ordinário e o redesenhar da jurisdição processual civil pela sentença (democrática) liminar de mérito. Curitiba: Juruá, 2012.

JESSUP, Philip C. Direito Transnacional. Tradução Carlos Ramires Pinheiro da Silva. Rio de Janeiro: Fundo de Cultura, 1965.

LATOUR, Bruno. Nous n'avons jamais été modernes. Essai d'anthropologie symétrique. Paris: La Découverte/Poche, 2013.

LIMBERGER, Têmis. SALDANHA, Jânia M.L. Cibercidadania no mundo globalizado: o desafio das novas tecnologias e a concretização dos direitos humanos nas democracias contemporâneas. Anuário de Derecho constitucional latinoamericano. Ano XVIII. Bogotá: Fundación Adenauer, 2012, p. 215-230.

MENEZES, Wagner. O direito internacional contemporâneo e a teoria da transnormatividade. In: PENSAR: Revista de Ciências Jurídicas. Vol. 12, nº 1, 2007. Disponível em: http://ojs.unifor.br/index.php/rpen/ article/view/1084. Acesso em 18 jun 2016.
NASSER, Salem Hikmat. Direito Global em pedaços: Fragmentação, Regimes e Pluralismo. In: Revista de Direito Internacional - Brazilian Journal of International Law. Vol. 12, n², 2015. Disponível em: http://www.publicacoesacademicas.uniceub.br/index.php/rdi/article/ view/3707/pdf. Acesso em 14 jul 2016.

OST, François. O tempo do direito. Tradução de Maria Fernanda Oliveira. Lisboa: Instituto Piaget, 1999.

SALDANHA, Jânia Maria Lopes. Os desafios do "Império Cibernético" na era da aceleração e da informação: Um "sexto" continente de liberdade perfeita ou de controle perfeito. In: TYBUSCH, Jerônimo et al (org). Direitos Emergentes na sociedade globa: Anuário do Programa de Pós-Graduação em Direito da UFSM. Ijuí: Editora Unijuí, 2013, p. 173-220.

. Cosmopolis. Edizioni Classi. Firenzi, Parigi, Porto Alegre, 2016, p. 276.

BRUM, Márcio Morais; MELLO, Rafaela da Cruz. As novas tecnologias da informação e comunicação entre a promessa de liberdade e o risco de controle total: estudo da jurisprudência do sistema interamericano de direitos humanos. In: Anuario mexicano de Derecho Internacional. Vol. XVI. Jan/ Dez. 2016. p. 461-498.

SANTOS, Boaventura de Sousa. Refundación del Estado em la América Latina. Perspectivas desde uma epistemologia del sur. Instituto Internacional Derecho y Sociedad. Programa democracia y transformación global. Lima, 2010. Disponível em: http://www.boaventuradesousasantos. pt/media/Refundacion\%20del\%20Estado_Lima2010. pdf. Acesso em 10 jun 2016.

SUPIOT, Alain. État social et mondialisation: analyse juridique des solidarités. In: Cours "De la gouvernement par le lois à la gouvernance par les nombres. Collége de France, 2013. Disponível em: https://www.college-de-france.fr/media/alain-supiot/UPL2335835739398687161_ supiot.pdf. Acesso em 15 jun 2016.

O Espirito de Filadélfia. A justiça social diante do mercado total. Tradução de Tânia do Valle Tschiedel. Porto Alegre: Sulina, 2014.

La Gouvernance par les nombres. Nantes: Fayard: Poids et mesures du monde, 2015.

VARELLA, Marcelo. Internacionalização do Direito: superação do paradigma estatal e a insuficiência das estruturas de diálogos. In: Revista de Direito Internacio- 
nal - Brazilian Journal of International Law. Vol. 9, $\mathrm{n}^{\circ} 4$, 2012. Disponível em: http://www.publicacoesacademicas.uniceub.br/index.php/rdi/article/view/2203/pdf. Acesso em 14 jul 2016.

TISA. Anexo sobre Transparência. Disponível em: https:/ / wikileaks.org/tisa/document/20140416_Annex-onTransparency/20140416_Annex-on-Transparency.pdf.
Acesso 05 jul 2016.

ŽIŽEK, Slavoj. How capital captured politics. In: The Guardian. 13 de Julho de 2014. Disponível em: https:/ / www.theguardian.com/commentisfree/2014/jul/13/ capital-politics-wikileaks-democracy-market-freedom. Acesso 05 jul 2016. 
Para publicar na Revista de Direito Internacional, acesse o endereço eletrônico www.rdi.uniceub.br ou www.brazilianjournal.org.

Observe as normas de publicação, para facilitar e agilizar o trabalho de edição. 